\title{
The effect of surface treatment AISI 316L welded joints on its corrosion behaviour in chloride solution
}

\author{
L. Vrsalović ${ }^{1 *}$, T. Paić ${ }^{2}$, V. Alar ${ }^{3}$, I. Stojanović ${ }^{3}$, S. Jakovljević ${ }^{3}$, S. Gudić ${ }^{1}$, I. Smoljko $^{1}$ \\ ${ }^{1}$ Faculty of Chemistry and Technology, University of Split, Teslina 10/V, 21000 Split, Croatia \\ ${ }^{2}$ MIAB d.o.o., Dolačka 21, 22000 Šibenik, Croatia \\ ${ }^{3}$ Faculty of Mechanical Engineering and Naval Architecture, University of Zagreb, \\ Ivana Lučića 1, p. p. 102, 10002 Zagreb, Croatia
}

Received 11 June 2014, received in revised form 17 June 2015, accepted 22 June 2015

\begin{abstract}
Investigation of different surface treatment effects on the corrosion resistance of AISI 316L stainless steel welded joints is presented in this paper. The research was conducted using gravimetric tests in $6 \mathrm{wt} . \%$ ferric chloride solution as well as polarization measurements in $1 \mathrm{~mol} \mathrm{dm}{ }^{-3} \mathrm{NaCl}$ solution. Additionally, the mechanism of corrosion attack developed on the steel surface was analyzed by optical microscopy, scanning electron microscopy and energy dispersive X-ray analysis. Before the measurements, the surface of stainless steel welded joints samples was treated by ultrasonic cleaning in ethanol (sample A), ultrasonic cleaning and pickling (sample B), ultrasonic cleaning, pickling and passivation (sample C) and grinding, polishing, ultrasonic cleaning, pickling and passivation (sample D). The results show that the corrosion resistance of 316L SS welded joints increased due to the surface treatment.
\end{abstract}

K e y word s: 316L stainless steel, corrosion, polarization, surface treatment, welding

\section{Introduction}

Stainless steels are important engineering materials widely used in a variety of industries due to their appropriate mechanical properties, weldability, and high corrosion resistance [1-6]. Corrosion resistance of stainless steel is related to the formation of an insoluble, relatively uncreative chromium oxide-hydroxide enriched passive surface film that forms naturally in the presence of oxygen (self-passivation). The passive layers thickness increases to approximately $10 \mathrm{~nm}$ and remains transparent $[7,8]$. Stainless steels have good weldability, but welding can increase their susceptibility to localized corrosion because the welding process can result in changes of microstructures, the formation of thermal oxide (heat tint) and residual stresses $[3,8$, 9]. Welding heat causes thickening of the chromium-rich oxide surface layer in the joint area by drawing the oxide layer away from adjoining areas and thus depleting their chromium levels, consequently lowering the steel corrosion resistance. Depending on the welding conditions in the joint area, a characteristic discolouration might occur, the colour of which depends on the temperature of exposure. The growth of the thermal oxide film on the stainless steels surface locally destroys the passive film. The breakdown of passivity is caused by compressive stresses in the superficial layer of the respective stainless steel which arise primarily due to an increase in the volume of various oxide phases since the volume of generated oxide is larger than the volume of metal. Therefore, the presence of thermal oxides usually enhances the liability of stainless steel to pitting due to its heterogeneous chemical composition, various defects, and stresses. The thermal oxides should be removed by various mechanical, chemical, and electrochemical procedures with the purpose of restoring the original resistance of the material to pitting [8-10].

Different methods, such as grinding and brushing, pickling with acid solutions or a pickling paste, polishing, electropolishing, and passivation have been developed for removing the heat tints and increase the corrosion resistance of stainless steels [8, 9, 11-14].

Grinding or wire brushing might be insufficiently 
Table 1. Chemical composition of AISI 316L (wt.\%)

\begin{tabular}{ccc}
\hline Element & Base material & Weldment \\
\hline $\mathrm{C}$ & 0.03 & 0.09 \\
$\mathrm{Si}$ & 0.51 & 0.26 \\
$\mathrm{Mn}$ & 1.72 & 1.75 \\
$\mathrm{~V}$ & 0.11 & 0.09 \\
$\mathrm{Cu}$ & 0.35 & 0.39 \\
$\mathrm{Cr}$ & 17.28 & 17.01 \\
$\mathrm{Mo}$ & 2.02 & 2.08 \\
$\mathrm{Ni}$ & 9.77 & 10.08 \\
$\mathrm{Fe}$ & balance & balance \\
\hline
\end{tabular}

effective to repair a heat-tinted region. Such abrading operations may only smear the heat tint oxide and embed the residual scale into the surface, expose the chromium depleted layer beneath the heat tint oxide, and contaminate the surface with ferrous particles that were picked up by the grinding wheel or wire brush.

Treatment of a heat-tinted region with only a pickling paste or acid solution can stain or even corrode the base metal if the solution is overly aggressive or is allowed to contact the surface for an extended time. If the acid is too weak, a chromium depleted scale residue could remain on the surface, even if the chromium-depleted layer was completely removed by a grinding operation [14].

Mixtures of $\mathrm{HNO}_{3}-\mathrm{HF}$ are the most commonly used pickling solutions for austenitic stainless steels due to their high effectiveness [12]. HF acts as a generator of $\mathrm{H}^{+}$ions, a complexing agent for $\mathrm{Fe}^{3+}$ and $\mathrm{Cr}^{3+}$ ions, a potential redox stabilizer of solutions and an effective deactivator of the passive film. $\mathrm{HNO}_{3}$ acts as a generator of $\mathrm{H}^{+}$ions, an agent for raising the redox potential, a passivating agent, an oxidizing agent of metal and a dissolution agent of oxide scales. Its disadvantages are related to the formation of nitrate effluents and nitrous gas in emissions during pickling.

The aim of this investigation was to determine the influence of different surface treatment methods for removing heat tints on AISI 316L welded joints samples on their corrosion resistance. The mixture of nitric, hydrofluoric acid and hydrogen peroxide was used as a pickling solution because hydrogen peroxide suppressed the emission of nitrous gases in the atmosphere [12].

\section{Experimental procedure}

The composition of the investigated AISI 316L stainless steel is given in Table 1.

Steel samples for corrosion testing were joined by TIG welding process with the austenite electrode in the inert argon atmosphere. Rectangular specimens (approximately $50 \times 25 \times 3 \mathrm{~mm}^{3}$ ) were used for gravimetric measurements which were carried out in $6 \mathrm{wt} . \%$ $\mathrm{FeCl}_{3} \times 6 \mathrm{H}_{2} \mathrm{O}$ solution thermostated on $25 \pm 1^{\circ} \mathrm{C}$ for $72 \mathrm{~h}$, due to the standard ASTM G-48 tests (practice A) [15]. According to the surface treatment the specimens were divided into three categories:

- ultrasonic treatment in ethanol and rinsing with deionized water (sample A),

- ultrasonic treatment in ethanol, chemical pickling in pickling solution $\left(10 \% \mathrm{HNO}_{3}+10 \% \mathrm{HF}+10 \%\right.$ $\mathrm{H}_{2} \mathrm{O}_{2}$ ) during 40 min and rinsing with deionized water (sample B),

- ultrasonic treatment in ethanol, chemical pickling in pickling solution $\left(10 \% \mathrm{HNO}_{3}+10 \% \mathrm{HF}+\right.$ $10 \% \mathrm{H}_{2} \mathrm{O}_{2}$ ) during $40 \mathrm{~min}$, passivation in $25 \%$ nitric solution during $30 \mathrm{~min}$, and rinsing with deionized water (sample C).

Before the experiment, each specimen was weighed on the Metler Toledo model AB204-S analytical balance, with the precision of $0.1 \mathrm{mg}$. The samples were immersed into the $\mathrm{FeCl}_{3} \times 6 \mathrm{H}_{2} \mathrm{O}$ solution for $72 \mathrm{~h}$. Upon completion of the experiment, the samples were extracted, rinsed with deionized water, dried and finally weighed again at room temperature.

DC electrochemical measurements were performed with Princeton Applied Research PAR M273A potentiostat/galvanostat. The working surface area of the samples was $2.1 \mathrm{~cm}^{2}$, and the electrolyte was $1 \mathrm{~mol} \mathrm{dm}{ }^{-3} \mathrm{NaCl}$ solution at a temperature of $25^{\circ} \mathrm{C}$. A three-electrode cell was utilized, where the working electrode was a stainless steel specimen, whereas the counter and the reference electrodes were represented by a platinum foil and saturated calomel electrode placed in Luggin capillary. Linear polarization measurements were performed at a scan rate of $0.166 \mathrm{mV} \mathrm{s}^{-1}$, in the potential range of $\pm 20 \mathrm{mV}$ with respect to the corrosion potential $\left(E_{\text {corr }}\right)$. Potentiodynamic polarization measurements were performed at the scan rate of $0.166 \mathrm{mV} \mathrm{s}^{-1}$, in the potential range from -0.5 to $0.5 \mathrm{~V}$.

According to the surface treatment the specimens for the electrochemical measurements were divided into four categories:

- ultrasonic cleaning in ethanol and rinsing with deionized water (sample A),

- ultrasonic cleaning in ethanol, chemical pickling in pickling solution $\left(10 \% \mathrm{HNO}_{3}+10 \% \mathrm{HF}+10 \%\right.$ $\mathrm{H}_{2} \mathrm{O}_{2}$ ) during 40 min and rinsing with deionized water (sample B),

- ultrasonic cleaning in ethanol, chemical pickling in pickling solution $\left(10 \% \mathrm{HNO}_{3}+10 \% \mathrm{HF}+10 \%\right.$ $\mathrm{H}_{2} \mathrm{O}_{2}$ ) during 40 min, passivation in $25 \%$ nitric solution during $30 \mathrm{~min}$ and rinsing with deionized water (sample C),

- mechanical grinding with different grades of SiC paper down to 1000 grit, polishing with polishing suspensions, ultrasonic cleaning in ethanol, chemical 
Table 2. Results of gravimetric measurements in $\mathrm{FeCl}_{3}$ solution

\begin{tabular}{cccc}
\hline Sample & $m_{1}(\mathrm{~g})$ & $m_{2}(\mathrm{~g})$ & $\Delta m(\mathrm{~g})$ \\
\hline $\mathrm{A}$ & 23.9119 & 23.3368 & 0.5751 \\
$\mathrm{~B}$ & 23.6092 & 23.1854 & 0.4238 \\
$\mathrm{C}$ & 27.1085 & 26.7712 & 0.3373 \\
\hline
\end{tabular}

pickling in pickling solution $\left(10 \% \mathrm{HNO}_{3}+10 \% \mathrm{HF}\right.$ $+10 \% \mathrm{H}_{2} \mathrm{O}_{2}$ ) during $40 \mathrm{~min}$, passivation in $25 \%$ nitric solution during $30 \mathrm{~min}$ and rinsing with deionized water (sample D).

The surface morphology of the samples after the potentiodynamic measurements was examined by scanning electron microscopy (SEM) Tescan equipped with energy dispersive spectrometer (EDS) Oxford Instruments.

\section{Results and discussion}

\subsection{Gravimetric results}

The variation of the mass loss obtained for AISI $316 \mathrm{~L}$ welded samples after the $72 \mathrm{~h}$ immersion in 6 wt. $\% \mathrm{FeCl}_{3} \times 6 \mathrm{H}_{2} \mathrm{O}$ solution is shown in Table 2 . The surface of the samples was photographed with a digital camera in macro mode as well as with an optical microscope with a low magnification $(40 \times)$ as shown in Fig. 1.

The heat tints are clearly visible on untreated welded sample surface before immersion in $\mathrm{FeCl}_{3}$ solution (Fig. 1a). The colours of the surface thermal oxide depend on the temperature to which the samples were exposed during the welding. The heating temperature of $200{ }^{\circ} \mathrm{C}$ causes no changes in austenitic stainless steel, and the oxide film remains transparent. At higher temperatures, a semitransparent thicker oxide film developed on the surface (light yellow around $400^{\circ} \mathrm{C}$, brown red around $650^{\circ} \mathrm{C}$ and greenish and cobalt blue at 800 $900{ }^{\circ} \mathrm{C}$ ). Heat at a temperature of $1000^{\circ} \mathrm{C}$ and higher produces a thicker thermal oxide film, which is opaque and brown-grey $[11,16,17]$. All these colours can be seen on the surface of steel sample.

Figures 1b,c show the surface of sample A after $72 \mathrm{~h}$ immersion in $\mathrm{FeCl}_{3}$ solution. The colours on the surface are fading during the exposure to ferric chloride solution due to slow dissolution of thermal oxides. As the thermal oxides were not removed by ultrasonic cleaning in ethanol and rinsing with deionized water before immersion, the surface of the sample has many sites suitable for the nucleation of pits during the exposure to $\mathrm{FeCl}_{3}$ solution, which results in the appearance of many pits on the surface, and the highest mass loss.

Chemical pickling ion (sample B) and pickling and
Ta b l e 3. The values of polarization resistance from linear polarization measurements

\begin{tabular}{cc}
\hline Sample & $R_{\mathrm{p}}\left(\mathrm{k} \Omega \mathrm{cm}^{2}\right)$ \\
\hline A & 61.420 \\
B & 78.561 \\
C & 95.921 \\
D & 103.415 \\
\hline
\end{tabular}

passivation in $\mathrm{HNO}_{3}$ solution (sample C) completely removed the heat tints from the steel samples and restored the oxide film on its surface (Fig. 1d-g). Samples treated in this way have a smaller mass loss, and the pits are visible only under a microscope. The highest corrosion resistance has those samples whose surface was chemically pickled and passivated before immersion.

\subsection{Polarization measurements}

Linear polarization measurements were performed to determine the influence of different surface treatments on polarization resistance of the samples. The polarization resistance strongly depends on the passive film, and it is a measure of corrosion resistance of the material in the environment [18].

Results of investigations are presented in Table 3.

It can be seen from Table 3 that the highest value of polarization resistance is shown by the sample whose surface has undergone complete surface treatment (sample D) while the lowest values of polarization resistance are shown by the sample A whose surface was ultrasonically cleaned in ethanol and rinsed with deionized water. This is in accordance with the results of Baron and associates [19, 20] which showed that the chemical and electrochemical surface treatment improved the corrosion resistance of AISI 316L stainless steel compared to mechanically polished surface. Reduction of surface roughness leads to an increase in the values of polarization resistance [18], and the minimum surface roughness has the sample D.

In Fig. 2 the polarization curves are presented, showing the corrosion behaviour of AISI 316L in $1 \mathrm{~mol} \mathrm{dm}{ }^{-3} \mathrm{NaCl}$ solution after four different surface treatments. The corrosion parameters deduced from the polarization curves are listed in Table 4.

All samples show similar polarization behaviour. The most pronounced difference between these samples is related to the span of the passive region. For ethanol ultrasonically cleaned sample, the passive region is limited by the current density increase at pitting potential $\left(E_{\mathrm{p}}\right)$ approximately at $-0.007 \mathrm{~V}$ (sample A). Chemical pickling extends the passive region due to increased pitting potential up to $0.193 \mathrm{~V}$ (sam- 

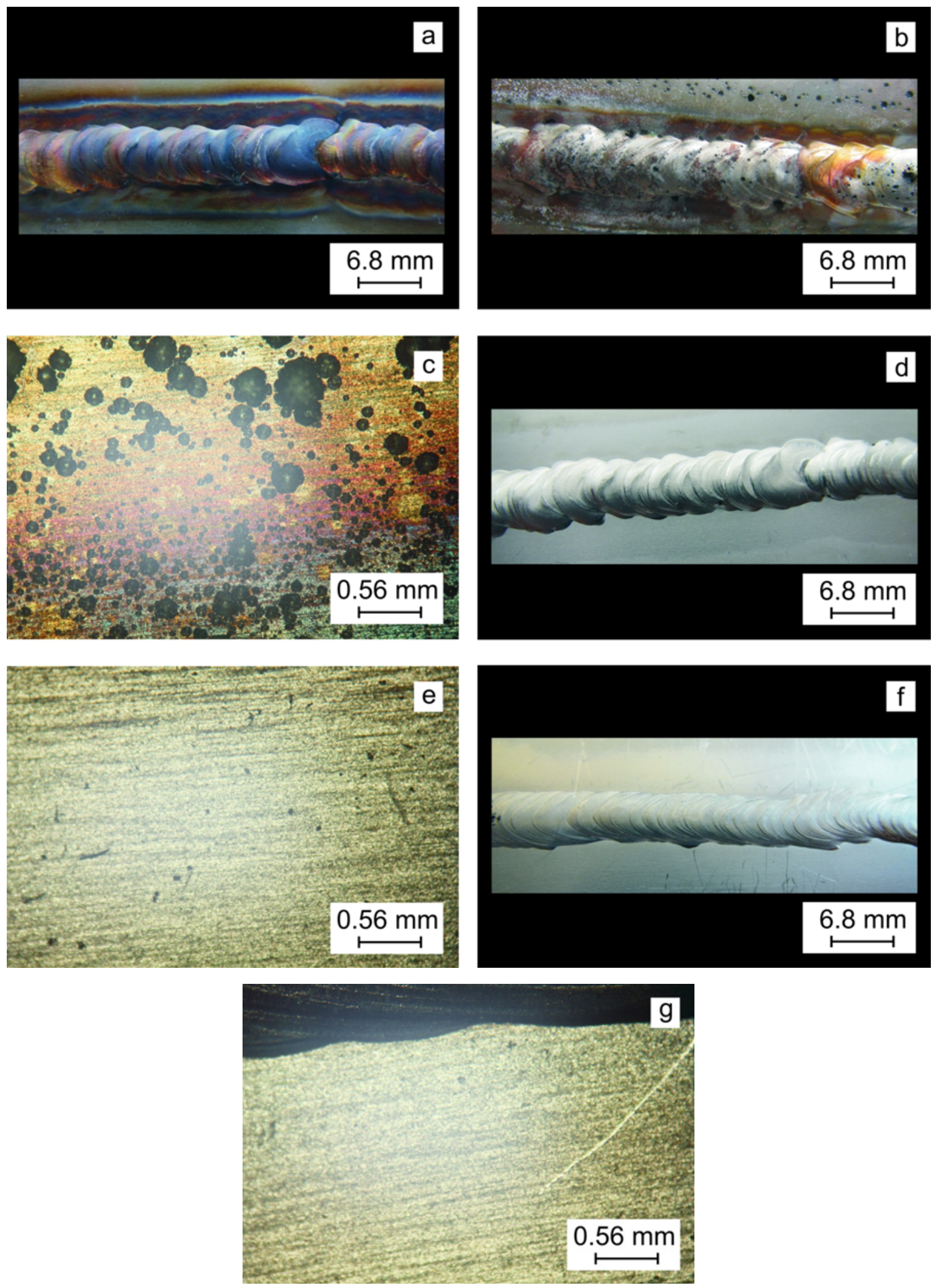

Fig. 1. Photographs of the AISI 316L samples for gravimetric measurements: (a) after welding and before any treatment, (b) after immersion in $\mathrm{FeCl}_{3} \times 6 \mathrm{H}_{2} \mathrm{O}$ solution for $72 \mathrm{~h}$, treated with ultrasonic treatment in ethanol and rinsed with deionized water before immersion (sample A), (c) optical micrographs of surface of sample A, (d) after immersion in $\mathrm{FeCl}_{3} \times 6 \mathrm{H}_{2} \mathrm{O}$ solution for $72 \mathrm{~h}$, treated with ultrasonic treatment in ethanol, chemically pickled in pickling solution before immersion (sample B), (e) optical micrographs of surface of sample B, (f) after immersion in $\mathrm{FeCl}_{3} \times 6 \mathrm{H}_{2} \mathrm{O}$ solution for $72 \mathrm{~h}$, treated with ultrasonic treatment in ethanol, chemically pickled in pickling solution and passivated in $25 \%$ nitric solution before immersion (sample C), (g) optical micrographs of surface of sample C. 
Table 4 . The values of electrochemical parameters from potentiodynamic polarization measurements

\begin{tabular}{ccccc}
\hline Sample & $i_{\text {corr }}\left(\mu \mathrm{A} \mathrm{cm}^{-2}\right)$ & $E_{\text {corr }}(\mathrm{V})$ & $E_{\mathrm{p}}(\mathrm{V})$ & $\left(E_{\mathrm{p}}-E_{\text {corr }}\right)(\mathrm{V})$ \\
\hline A & 0.73 & -0.273 & -0.007 & 0.266 \\
B & 0.54 & -0.370 & 0.193 & 0.563 \\
C & 0.42 & -0.295 & 0.345 & 0.640 \\
D & 0.38 & -0.345 & 0.475 & 0.820 \\
\hline
\end{tabular}

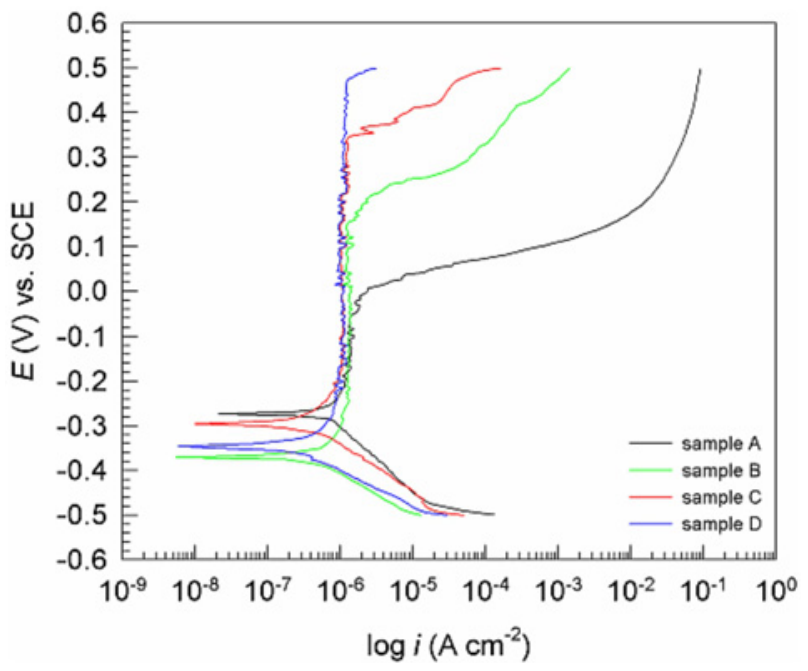

Fig. 2. Potentiodynamic polarization curves of AISI 316L welded samples with different surface treatment.

ple B), and chemical pickling and passivation extend the passive region by increasing the pitting potential to $0.345 \mathrm{~V}$ (sample $\mathrm{C}$ ). The widest passive area was achieved by treating the sample by mechanically grinding and polishing, followed up with ethanol ultrasonically cleaning, chemical pickling and passivation $\left(E_{\mathrm{p}}-E_{\text {corr }}=0.820 \mathrm{~V}\right)$. Thus, mechanical treatments of welded joints, as well as chemical pickling and passivation have a beneficial effect on the corrosion stability in $1 \mathrm{~mol} \mathrm{dm}{ }^{-3} \mathrm{NaCl}$ solution and decrease the susceptibility of AISI 316L to localized corrosion breakdown. This is in accordance with the previous investigations of Alar et al. [6, 21], which showed that decreasing the surface roughness significantly increased the resistance to pitting and expanded the passivation area on the AISI 316L stainless steel. It is also found that the protective properties of the passive film on stainless steel depend on the concentration of $\mathrm{HNO}_{3}$ which is used for passivation and that the optimum concentration is between $20-25 \%$, the concentration that has been used for passivation in this investigation.

Chemical pickling of $316 \mathrm{~L}$ stainless steel in pickling solution leads to the removal of heat tints, thermal oxides, and other possible surface irregularities. After chemical pickling and rinsing, the natural oxide film develops on steel surface which has corrosion protective properties. It was found that chemical pickling

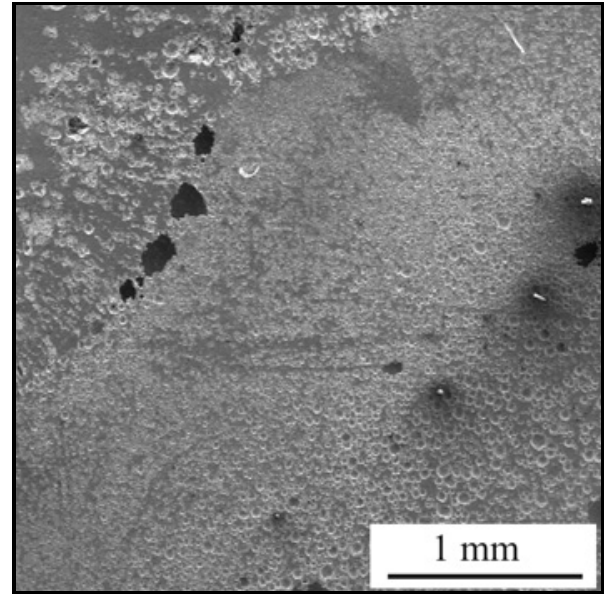

Fig. 3. SEM image of sample A after potentiodynamic polarization measurement.

Table 5. EDX analysis inside pit

\begin{tabular}{crr}
\hline Element & $($ wt.\% $)$ & $($ at.\% $)$ \\
\hline $\mathrm{Cr}$ & 25.53 & 26.95 \\
$\mathrm{Mn}$ & 3.39 & 3.39 \\
$\mathrm{Fe}$ & 67.39 & 66.22 \\
$\mathrm{Ni}$ & 3.69 & 3.45 \\
\hline
\end{tabular}

and passivation increases the ratio of $\mathrm{Cr} / \mathrm{Fe}$ in passive film $[22,23]$.

\subsection{SEM/EDX analysis}

After the potentiodynamic polarization measurements, the surface morphology of the samples was examined by SEM-EDX analysis. SEM image of sample A (Fig. 3) reveals severe pitting damages in the interface weld material/heat affected zone.

Detail inspection of the pit is given in Fig. 4, along with the EDX analysis inside the pit. It is evident that the composition of the material inside the pit was changed in relation to its initial state. The higher intensities of $\mathrm{Cr}$ and $\mathrm{Mn}$ and lower intensities of $\mathrm{Ni}$ and Fe have been observed inside the pit area in relation to the undamaged area of the sample.

Table 5 shows the results of the element analysis 


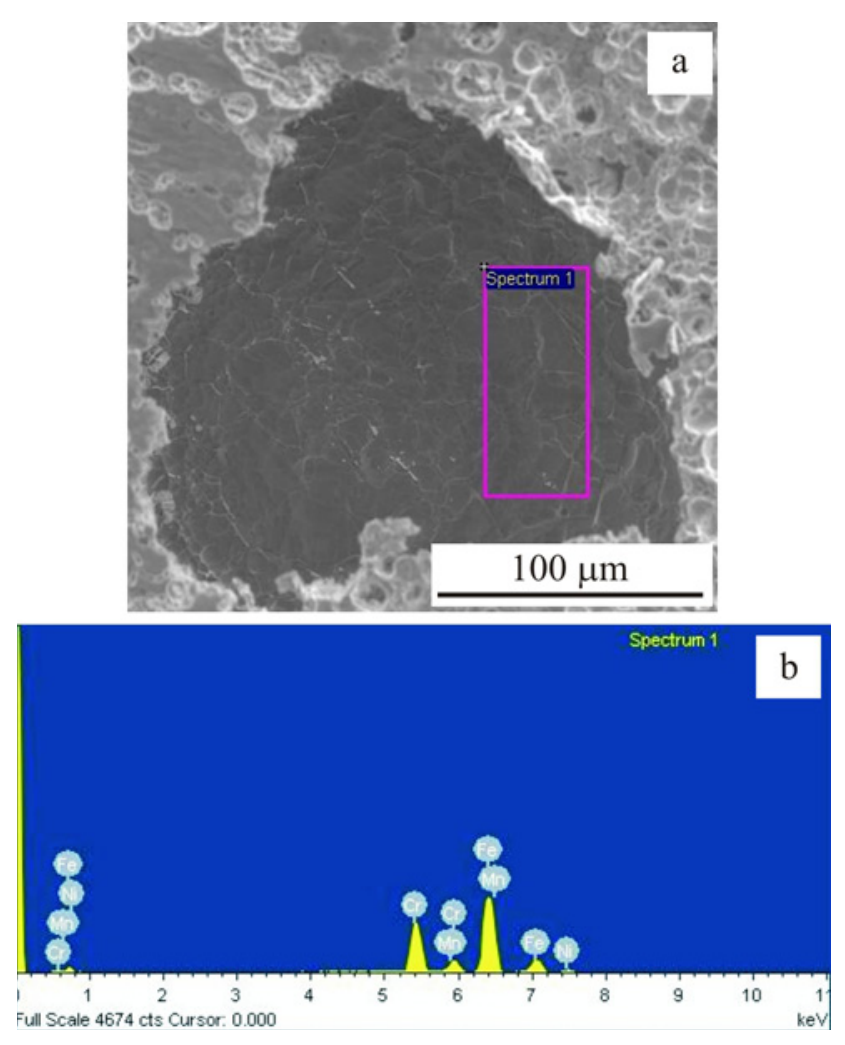

Fig. 4. SEM image of the pit on the surface of sample A (a), with the EDX spectrum inside of pit (b).

inside the pit expressed in wt.\% and at.\%. Lower wt.\% of $\mathrm{Fe}$ and $\mathrm{Ni}$ inside the pit is the result of their rapid dissolution in relation to compounds $\mathrm{Cr}$ and $\mathrm{Mn}$, leading to enrichment of the surface of the pit with $\mathrm{Cr}$ and Mn.

Figure 5a shows the SEM image of sample C after the potentiodynamic polarization measurements, along with the EDX analysis of the point on the fusion line of weld $b$ ). The surface of the sample $\mathrm{C}$ is much smoother than the surface of sample A, without any visible corrosion damage. EDX analysis showed a small decrease in the weight percentage of Fe while the percentages of other elements remained almost unchanged, which confirmed a much higher corrosion resistance of steel sample treated by pickling and passivation.

EDX line analysis of the corroded sample (sample A) was performed to detect changes in the surface composition of the corroded sample at the interface weldment/base material (Fig. 6). Variation in the contents of iron, nickel, chromium and manganese across the interface is given in Figs. 6b-e. Line analysis across the surface of the phase boundary weldment/base material revealed a sudden drop in intensity for all elements in the areas of pits on the surface of the sample.

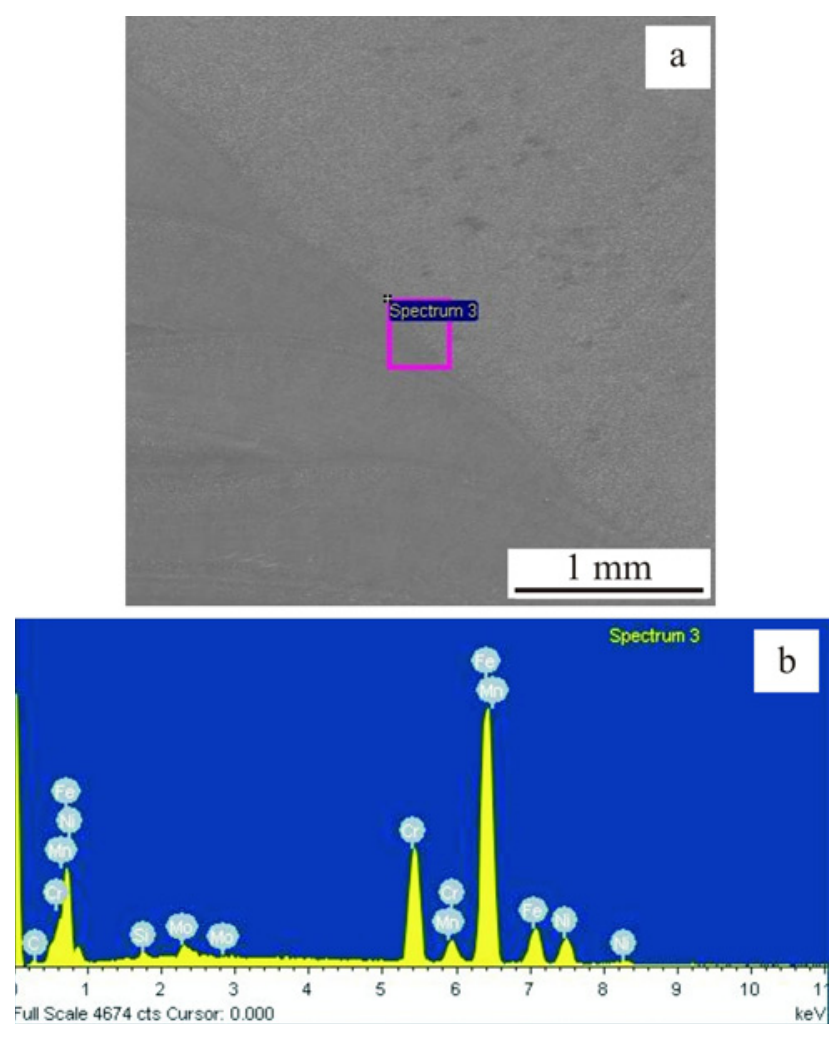

Fig. 5. SEM image of sample $\mathrm{C}$ after the potentiodynamic polarization measurements (a), with the EDX spectrum of the point on the fusion line of the weld (b).

Table 6. EDX-analysis of fusion line

\begin{tabular}{crr}
\hline Element & (wt.\%) & (at.\%) \\
\hline $\mathrm{Cr}$ & 17.04 & 16.20 \\
$\mathrm{Mn}$ & 2.25 & 2.03 \\
$\mathrm{Fe}$ & 64.58 & 57.18 \\
$\mathrm{Ni}$ & 10.01 & 8.43 \\
$\mathrm{Mo}$ & 2.20 & 1.13 \\
$\mathrm{C}$ & 3.44 & 14.18 \\
$\mathrm{Si}$ & 0.48 & 0.85 \\
\hline
\end{tabular}

\section{Conclusions}

Surface treatment of welded joints of AISI 316L stainless steel has a significant influence on the corrosion resistance. Removing the heat tints on the welded joint surfaces by chemical pickling and passivation of the sample significantly reduces the mass loss as well as the formation of surface corrosion damage, indicating a higher corrosion resistance of the treated samples.

Values of polarization resistance, pitting potential and the width of the passive area rises with the surface treatment of welds, and the highest values were 

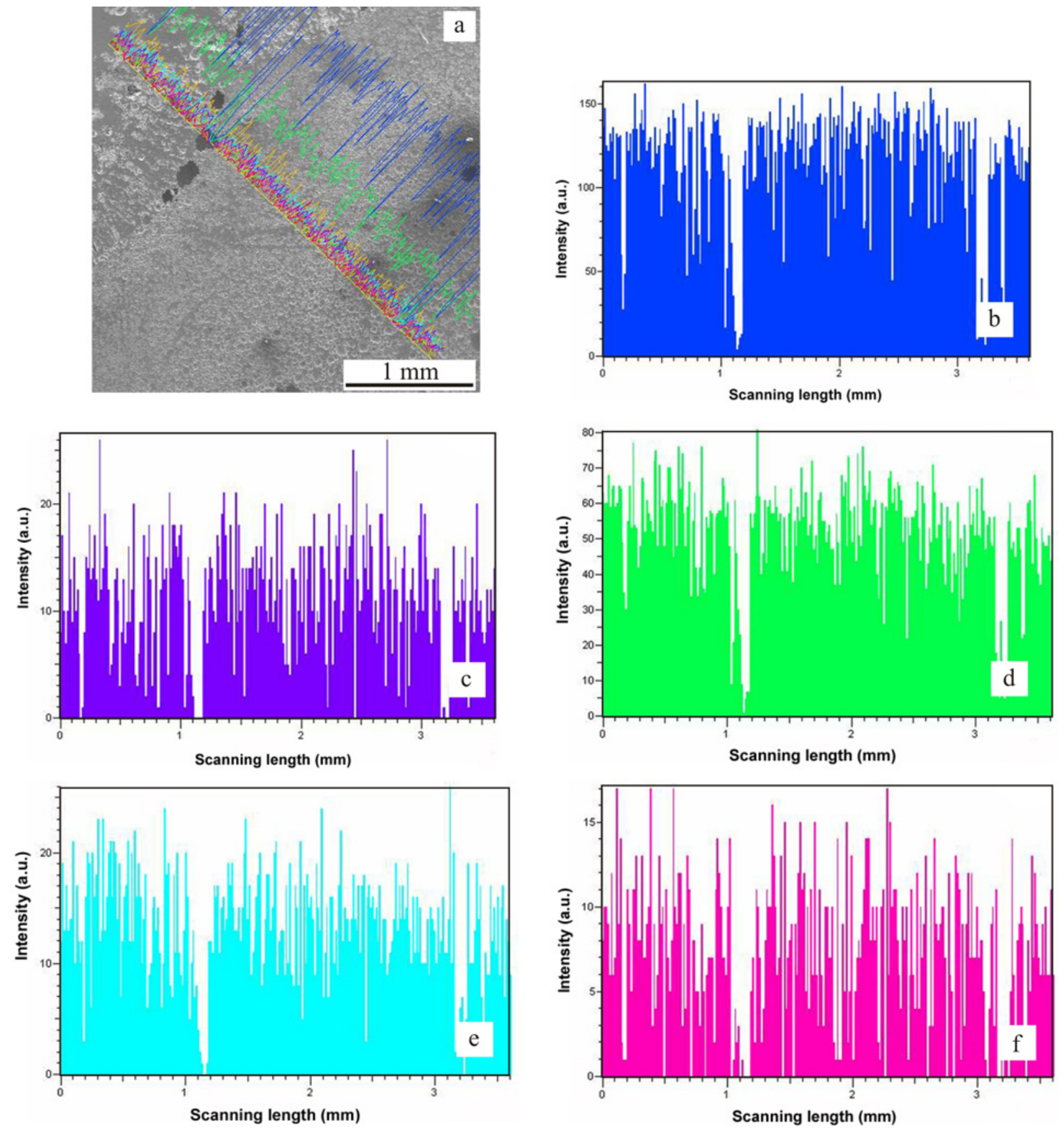

Fig. 6. EDS line-scan analysis of a sample at the interface weldment/base material (a), variation in the contents of iron (b), nickel (c), chromium (d), manganese (e), and molybdenum (f).

obtained for the sample that has been processed by grinding, etching and passivation.

Results of SEM/EDX analysis of samples of stainless steel welds after potentiodynamic polarization measurements show that the sample with heat tint oxides on the surface suffers severe pitting corrosion damage, and the composition of elements inside the pits indicates intensive dissolution of $\mathrm{Fe}$ and Ni. Steel samples on which the heat tints were removed by surface treatment have a smoother surface, almost without any corrosion damage. EDX analysis showed a mi- nor reduction in the weight percentage of $\mathrm{Fe}$ while the percentages of other elements remained almost unchanged.

\section{References}

[1] Naha, S. K.: Science Reporter, 48, 2011, p. 52.

[2] Gedge, G.: J. Constr. Steel. Res., 64, 2008, p. 1194. doi:10.1016/i.jcsr.2008.05.006

[3] Xiong, J., Tan, M. Y., Forsyth, M.: Desalination, 327, 2013, p. 39. doi:10.1016/i.desal.2013.08.006 
[4] Dubey, R. S., Potdar, Y.: IJCT, 16, 2009, p. 334.

[5] Kožuh, S., Gojić, M., Vrsalović, L., Ivković, B.: Kovove Mater., 51, 2013, p. 53.

[6] Alar, V., Runje, B., Barišić, G.: Materialwiss. Werkstofftech., 41, 2010, p. 875. doi:10.1002/mawe.201000632

[7] Juraga, I., Simunović, V., Spaniček, Đ.: METABK, 46, 2007, p. 185.

[8] Labanowski, J., Glowacka, M.: Weld. Int., 25, 2011, p. 509. doi:10.1080/09507116.2010.540837

[9] Esih, I., Alar, V., Juraga, I.: Corros. Eng. Sci. Techn., 40, 2005, p. 110. doi:10.1179/174327805X46977

[10] Tuthill, A. H., Avery, R. E.: Mater. Perform., 38, 1999, p. 72 .

[11] Alar, V., Juraga I., Kapor, F.: MP Mater. Test., 49, 2007, p. 325.

[12] Li, L.-F., Celis, J.-P.: Can. Metall. Quart., 42, 2003, p. 365. doi:10.1179/000844303794406071

[13] Fajnor, P., Liptakova, T., Konstantova, V.: Materials Engineering, 17, 2010, p. 21.

[14] Davis, J. R.: Corrosion of Weldments. Materials Park, ASM International 2006.

[15] ASTM G48-03, Standard Test Methods for Pitting and Crevice Corrosion Resistance of Stainless Steels and Related Alloys by Use of Ferric Chloride Solution. West Conshohocken, ASTM International 2003.
[16] Alar, V., Alar, Ž., Rede, V.: MP Mater. Test., 50, 2008, p. 6.

[17] Somervuori, M. E., Johansson, L.-S., Heinonen, M. H., Hoecke, D. H. D., Akdut, N., Hanninen, H. E.: Mater. Corros., 55, 2004, p. 421. doi:10.1002/maco.200303753

[18] Wallinder, D., Pan, J., Leygraf, C., Delblanc-Bauer, A.: Corros. Sci., 41, 1999, p. 275. doi:10.1016/S0010-938X(98)00122-X

[19] Baron, A., Simka, W., Nawrat, G., Szewieczek, D., Krzyzak, A.: JAMME, 18, 2006, p. 55.

[20] Baron, A., Simka, W., Nawrat, G., Szewieczek, D.: JAMME, 31, 2008, p. 197.

[21] Alar, V., Barišić, G., Runje, B., Alar, Ž.: Materialwiss. Werkstofftech., 43, 2012, p. 725. doi:10.1002/mawe.201200854

[22] Noh, J. S., Laycock, N. J., Gao, W., Wells, D. B.: Corros. Sci., 42, 2000, p. 2069. doi:10.1016/S0010-938X(00)00052-4

[23] Jafari, E., Hadianfard, M. J.: J. Mater. Sci. Technol., 25, 2009, p. 611. 